\title{
EQUINE LEUKOENCEPHALOMALACIA ASSOCIATED WITH INGESTION OF CORN CONTAMINATED WITH FUMONISIN $B_{1}$
}

\author{
Carlos A. Mallmann*; Janio M. Santurio; Paulo Dilkin
}

Departamento de Medicina Veterinária Preventiva, Universidade Federal de Santa Maria, Santa Maria, RS, Brasil

Submitted: January 07, 1999; Returned to authors for corrections: April 08, 1999; Approved: July 30, 1999

\section{SHORT COMMUNICATION}

\begin{abstract}
This article describes clinical, etiologic and pathologic diagnosis of an outbreak of equine leukoencephalomalacia. Two samples of the corn consumed by the affected horses contained fumonisin $\mathrm{B}_{1}$ at levels of 46 and $53 \mu \mathrm{g} / \mathrm{g}$ and Fusarium moniliforme, a good in vitro mycotoxin producer.
\end{abstract}

Key words: corn, leukoencephalomalacia, fumonisin, Fusarium moniliforme, chromatography

Fumonisins are a group of toxic metabolites produced by Fusarium spp. and Alternaria spp. fungi, especially Fusarium moniliforme $(2,10,15)$, a species well adapted to tropical climates $(8,17)$. These mycotoxins have been detected in oats and corn-based food, even after pelletization $(5,19)$. Among the several types of fumonisin known, fumonisin $\mathrm{B}_{1}\left(\mathrm{FB}_{1}\right), \mathrm{B}_{2}\left(\mathrm{FB}_{2}\right)$, and $\mathrm{B}_{3}\left(\mathrm{FB}_{3}\right)$ have been isolated from naturally contaminated foods and feeds. $\mathrm{FB}_{1}$, the most toxic of these compounds (13), is produced in large amounts and is responsible for various toxicoses in domestic animals, including equine leukoencephalomalacia (ELEM) $(12,13)$, pulmonary edema and hydrothorax in pigs (6), diarrhea and reduced body weight in broiler chicks (8) and carcinogenity in rats (15). $\mathrm{FB}_{1}, \mathrm{FB}_{2}$ and $\mathrm{FB}_{3}$ are generally found in feed at a ratio of $8: 2: 1$ (18).

The clinical course of ELEM is directly related to the amount of toxin ingested and may be influenced by individual tolerance. Clinical disease may be observed from a few hours to several days after consumption of contaminated rations, but a correct diagnosis is normally possible after an average period of 72 hours. Feed containing more than $10 \mu \mathrm{g} / \mathrm{g}$ of $\mathrm{FB}_{1}$ is considered toxic and of high risk if administered to animals. Previous studies of ELEM outbreaks have shown that feed contaminated with 1 to $126 \mu \mathrm{g} / \mathrm{g}$ of $\mathrm{FB}_{1}$ produces clinical signs of the disease in horses $(12,19)$.

The aim of this short communication was to describe an outbreak of ELEM in horses and correlate the disease with the presence of both Fusarium moniliforme and $\mathrm{FB}_{1}$ in corn ingested by the affected animals.

The episode occurred in a farm located in southern Brazil, during the spring of 1996, when 3

\footnotetext{
* Corresponding author. Mailing address: Departamento de Medicina Veterinária Preventiva, Universidade Federal de Santa Maria, CEP 97105-900, Santa Maria, RS, Brasil. E-mail: mallmann@ccr.ufsm.br. Fax: (+5511) 220-8445
} 
to 4 years old thoroughbred horses ( 3 males and 1 female; approximate body weight: $400 \mathrm{Kg}$ ) were affected. The animals were being fed native grass supplemented with $2 \mathrm{~kg}$ of corn/horse/day. Three horses presented clinical signs of ELEM seven days after ingestion of contaminated ration and the forth horse showed similar signs three days later. All horses died within 18 to 30 hours from the start of clinical disease and were necropsied immediately after death. Brain tissue was macroscopically examined and selected areas were sampled for routine histopathology.

Two samples of corn fed to the affected horses were analysed for the presence of $\mathrm{FB}_{1}$. All the procedures used for extraction, purification, and quantification of $\mathrm{FB}_{1}$ by high-performance liquid chromatography (HPLC) (GBC Scientific Equipment Pty Ltd. - Victoria, Australia) were adapted from previous studies $(3,12) .10 \mathrm{~g}$ of ground corn were mixed with $50 \mathrm{ml}$ acetonitrile/water (50:50) and blended for $5 \mathrm{~min}$. This suspension was then filtered through Whatmann IV filter paper and $2 \mathrm{ml}$ of the filtrate was mixed with $6 \mathrm{ml}$ of deionized water. The diluted filtrate was then applied to a silica $\mathrm{C}_{18}$ cartridge $(500 \mathrm{mg}$ ) previously conditioned with $2 \mathrm{ml}$ of acetonitrile and $2 \mathrm{ml}$ of water. $\mathrm{FB}_{1}$ was eluted with $2 \mathrm{ml}$ of acetonitrile/water (70:30) and dried in liquid nitrogen and diluted in $200 \mu \mathrm{l}$ of acetonitrile/ water (70:30). $100 \mu 1$ of $\mathrm{FB}_{1}$ solution was added to an equal volume of $0.1 \mathrm{M}$ borate buffer and to 100 $\mu 1$ of o-phthaldialdehyde (OPA) solution (30 mg of OPA dissolved in $9.5 \mathrm{ml}$ of acetonitrile containing $0.5 \mathrm{ml}$ of 2-mercaptoetanol and stored in dark at $7{ }^{\circ} \mathrm{C}$ for less than 1 week). After 10 minutes, $200 \mu \mathrm{l}$ of $0.01 \mathrm{M}$ boric acid were added to the mixture. $20 \mu \mathrm{l}$ of chromatographic solution were analysed by a reverse-phase isocratic system with fluorescence detection. $\mathrm{FB}_{1}$ concentrations were determined under an excitation wavelength of $365 \mathrm{~nm}$ and emission wavelength of $460 \mathrm{~nm}$.

The mobile phase was prepared using a buffer of $0.1 \mathrm{M}$ sodium phosphate and acetonitrile $(60: 40)$. A $5 \mu \mathrm{m} \mathrm{C}_{18}(250 \times 4.6 \mathrm{~mm})$ column was used at a flow rate of $1 \mathrm{ml} / \mathrm{min}$, and quantification was determined by peak area.

Corn samples obtained from the warehouse, and suspected to be responsible for this outbreak, were grounded and cultured. 10 grams of corn kernels from each sample were added to $90 \mathrm{ml}$ of sterile distilled water to obtain a $10^{-1}$ stock dilution, from which ten fold serial dilutions up to $10^{-6}$ were made using the same diluent. Duplicate $1 \mathrm{ml}$ volumes of each dilution were added to Petri dishes containing 10 to $15 \mathrm{ml}$ of Potato Dextrose Agar (16). The plates were then incubated at $27^{\circ} \mathrm{C}$ for 5 days and observed daily. The fungal colonies recovered were identified according to Nelson (10). Colonies of Fusarium moniliforme isolated from the suspected corn were inoculated into Erlenmeyer flasks with $50 \mathrm{~g}$ of sterile corn at two different humidity levels (34 and 45\%), in triplicates. The cultures were homogenized and incubated at $27^{\circ} \mathrm{C}$ for 17 days, after which they were autoclaved, placed on trays and dried at $40^{\circ} \mathrm{C}$ for 15 hours, to facilitate $\mathrm{FB}_{1}$ extraction and quantification.

Contamination of corn by fumonisin and the consequent onset of ELEM are known to occur worldwide $(5,7,12)$. A seasonal occurrence of ELEM has also been described, associated with the ingestion of mouldy corn and the isolation of Fusarium moniliforme from feeds (9). In Brazil, the highest frequencies of this toxicosis were recorded from the end of fall until the beginning of spring $(1,4,11)$.

Seasonality of ELEM outbreaks may be linked with the humidity levels required for growth of Fusarium moniliforme and production of $\mathrm{FB}_{1}$ in significant amounts, or, additionally, with the need to supplement horse diets with corn-based rations during shortage of native pasture. In this report, each horse received $2 \mathrm{~kg}$ /day of corn, and two samples of this feed were found to be contaminated with $\mathrm{FB}_{1}$ at levels of 46 and $53 \mu \mathrm{g} / \mathrm{g}$ (Fig. 1).

The concentrations of fumonisin $\mathrm{B}_{1}$ detected in our study were at least five times higher than the known toxic concentration for horses $(12,20)$. Contamination with $\mathrm{FB}_{3}$ and $\mathrm{FB}_{2}$ at levels of 7 and $13 \mu \mathrm{g} / \mathrm{g}$, respectively, has been reported for corn administered to horses that also developed ELEM (20).

In this outbreak, the delay in the onset of clinical signs was probably due to the relatively low amounts of $\mathrm{FB}_{1}$ present in the feed. Although the signs consisted of blindness, uncoordination, anterior limb crossing, circling, aggressiveness, recumbency and eventual death, and were thus indicative of ELEM. The definitive diagnosis was based on determination of $\mathrm{FB}_{1}$ levels in the corn feed as well as gross and histological findings. Histopathology revealed areas of necrosis in the white matter of the CNS yet these lesions were not extensive. According to Kellerman et al. (7), who studied the effects of chronic exposure to $\mathrm{FB}_{1}$, a reduced spread of necrosis could be related to short time of exposure to the toxin. Gross changes 
Figure 1. HPLC chromatograms of fumonisin $\mathrm{B}_{1}$.

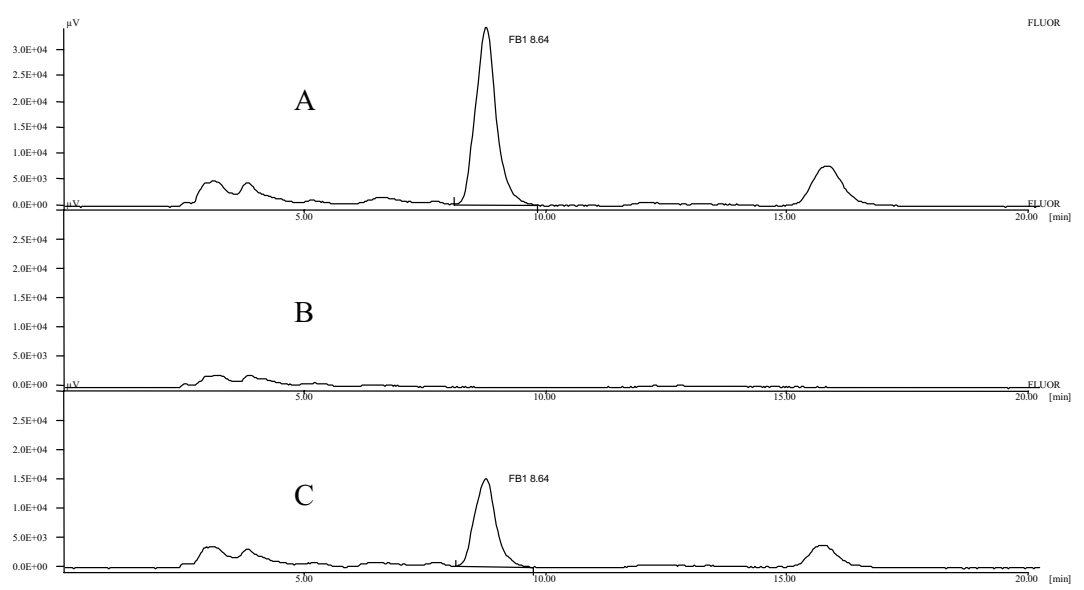

A - Chromatogram of $\mathrm{FB}_{1}$ standard $(10 \mu \mathrm{g} / \mathrm{ml})$.

B - Chromatogram of negative sample.

C - Chromatogram of corn sample which caused the outbreak of ELEM $\left(53 \mu \mathrm{g} / \mathrm{g}\right.$ de FB $\left.\mathrm{FB}_{1}\right)$.

observed at necropsy in our study were restricted to the nervous system and consisted of cerebral hemisphere asymmetry, mild edema, and increased tissue softness. Focal areas of haemorrhage were randomly distributed over the subcortical white matter, the basal nuclei, and the mid brain. Microscopically, CNS lesions were observed in the white matter and consisted of spongiform degeneration, punctate haemorrhage and perivascular haemorrhages.

The isolation of Fusarium moniliforme from rations administered to horses affected by ELEM has been reported in several outbreaks $(1,11)$. The isolated strain (LAMIC 2999/96) was shown to be a good producer of $\mathrm{FB}_{1}$. Cultures of this isolate yielded up to 440 and $670 \mu \mathrm{g} / \mathrm{g}$ when cultured in vitro, at humidity levels of 34 and $45 \%$, respectively. It was also observed that the concentration of $\mathrm{FB}_{1}$ was directly related to relative humidity, where levels between $34 \%$ and $45 \%$ were more efficient at inducing a high production of this mycotoxin at room temperature. Similar findings have also been reported by other authors (14).

The etiologic diagnosis of ELEM constitutes an important tool for the prevention of this toxicosis. The frequency of ELEM appears to be significantly higher in regions where weather conditions promote the growth of fungi (i.e., rainy seasons with moderate temperatures). A conclusive clinical diagnosis of ELEM is often very difficult due to the fact that the neurological signs are similar to those consequent to the neurological alterations that occur due to encephalitis and rabies. Therefore, a conclusive diagnosis must be based on gross and histopathologic alterations of the CNS together with the detection of fumonisin in contaminated rations.

\section{ACKNOWLEDGMENT}

We thank Vet. Med. Francisco Noll for his contribution with the clinical evaluation and Dr. Claudio S. L. Barros for the pathologic diagnosis.

\section{RESUMO}

\section{Leucoencefalomalácia eqüina associada à ingestão de milho contaminado por fumonisina $B_{1}$}

Descreve-se o diagnóstico clínico, etiológico e patológico de um surto de leucoencefalomalacia eqüina. Duas amostras do milho consumido pelos eqüinos afetados apresentaram 46 e $53 \mu \mathrm{g} / \mathrm{g}$ de fumonisina $\mathrm{B}_{1}$ e uma linhagem de Fusarium moniliforme, boa produtora da toxina em cultivos in vitro. 
Palavras-chave: milho, leucoencefalomalácia, fumonisina, Fusarium moniliforme, cromatografia.

\section{REFERENCES}

1. Barros, C.S.L. de; Barros, S.S. de; Santos, M.N.; Souza, M.A de Leucoencefalomácia em eqüinos no Rio Grande do Sul. Pesq. Vet. Bras., 4: 101-107, 1984.

2. Bezuidenhout, S.C.; Gelderblom, W.C.A.; Gorst-Allman, C.P.; Horak, R. M.; Marasas, W.F.O.; Spiteller, G.; Vleggaar, R. Struture elucidation of the fumonisins, mycotoxins from Fusarium moniliforme. J. Chem. Soc. Chem. Commun., 11: 743-745, 1988.

3. Binkerd, K.A.; Scott, D.H.; Everson, R.J.; Sullivan, J.M.; Robinson, F.R.; Fumonisin contamination of the 1991 Indiana corn crop and its effects on horses. Vet. Diag. Invest., 5: 653655, 1993.

4. Carvalho, F.S.R.; Coelho, H.E.; Ribeiro, S.M. Micotoxicose em eqüinos, causada pelo Fusarium moniliforme (relato de casos). Vet. Not., 1: 37-43, 1995.

5. Dupuy, J.; Bars, P. le; Boudra, H.; Termoestability of fumonisin B a mycotoxin from Fusarium moniliforme, in corn. Appl. Environ. Microbiol., 59: 2864-2867, 1993.

6. Haschek, W.M.; Motelin, G.; Ness, D.K.; Hall, W.F.; Vesonder, R.F.; Peterson, R. E.; Beasley, V. R. Characterization of fumonisin toxicity in orally and intravenously dosed swine. Mycopathologia, 117: 83-96, 1992.

7. Kellerman, T.S.; Marasas, W.F.O.; Thiel, P.G.; Gelderblom, W.C.A.; Cawood, M.; Coetzer, J.A.W Leukoencephalomalacia in two horses induced by oral dosing of fumonisin B. Ondertepoort J. Vet. Res., 57: 269-275, 1990.

8. Ledoux, D.R.; Brown, T.P.; Weibking, T.S.; Rottinghaus, G.E. Fumonisin toxicity in broiler chicks. J. Vet. Diag. Invest., 4: 330-333, 1992.

9. Meireles, M.C.A.; Corrêa, B.; Fischman, O.; Gambale, W.; Paula, C.R.; Chacon-Reche, N.O.; Pozzi, C.R. Mycoflora of the toxic feeds associated with equine leukoencephamalacia (ELEM) outbreaks in Brasil. Mycopathologia, 127: 183-188, 1994.

10. Nelson, P.E. Taxonomy and biology of Fusarium moniliforme. Mycopathologia, 117: 29-36, 1992.
11. Riet-Correa, F.; Meirelles, M.A.; Soares, J.M.; Machado, J.J.; Zambrano, A.F. Leucoencefalomalácia em eqüinos associado à ingestão de milho mofado. Pesq. Vet. Bras., 2: 27-30, 1982.

12. Ross, P.F.; Rice, L.G.; Reagor, J.C.; Osweiler, G.D.; Wilson, T.M.; Nelson, A.A.; Owens D.L.; Plattner, R.D.; Harlin, K.A.; Richard, J.L.; Colvin, B.M.; Banton, M.I. Fumonisin B concentrations in feeds from 45 confirmed equine leukoencephalomalacia cases. J. Vet. Diagn. Invest., 3: 238241, 1991.

13. Ross, P.F.; Nelson, P.E.; Owens, D.L.; Rice, H.A.; Nelson, H.A.; Wilson T.M. Fumonisin $\mathrm{B}_{2}$ in cultured Fusarium proliferatum, M-6104, causes equine leukoencephalomalacia. J. Vet. Diagn. Invest., 6: 263-265, 1994.

14. Schumacher, J.; Mullen, J.; Shelby, R.; Lenz, S.; Ruffin, D.C.; Kemppainen, B.W. An investigation of the role of Fusarium moniliforme in duodenitis/proximal jejunitis of horses. Vet. Human Toxicol., 37: 39-45, 1995.

15. Shephard, G.S.; Thiel, P.G.; Sydenham, E.W. Initial studies on the toxicokinetics of fumonisin $\mathrm{B}_{1}$ in rats. Food Chem. Toxicol., 30: 277-279, 1992.

16. Swanson, K. M. J.; Busta, F. F.; Peterson, E. H. Colony Count Methods. In: Vanderzant, C.; Splittoesser, D. S. (eds). Compendium of Methods for the Microbiological Examination of Foods. Third edition. American Public Health Association, New York, 1992, p. 75-95.

17. Sydenham, E.W.; Gelderblom, W.C.A.; Thiel, G.P.; Thiel, P.G.; Marasas, W.F.O. Evidence of the natural occurrence of fumonisin $\mathrm{B}_{1}$ a mycotoxin produced by Fusarium moniliforme, in corn. J. Agric. Food Chem., 38: 285-290, 1990.

18. Wilkins, P.A.; Vaala, W.E.; Zivotofsky, D.; Twitchell, E.D. A herd outbreak of equine leukoencephalomalacia. Cornell Vet., 84: 53-59, 1994.

19. Wilson, T.M.; Nelson, P.E.; Ryan, T.B. Linking leukoencephalomalacia to commercial horse rations. Vet. Med., 80: 63-69, 1985 .

20. Wilson, T.M.; Roos, P.F.; Rice, L.G.; Osweiler, G.D.; Nelson, H.A.; Owens, D.L.; Plattner, R.D.; Reggiardo, C.; Noon, T.H.; Pickrell, J.W. Fumonisin B levels associated with an epizootic of equine leukoencephalomalacia. J. Vet. Diagn Invest., 2: 213-216, 1990. 